\title{
A Narrative Review on the Phytochemistry, Nutritional Profile and Properties of
}

\section{Prickly Pear Fruit}

\begin{abstract}
Batool Sabtain, Rabia Farooq, Bakhtawar Shafique, Muhammad Modassar Ali Nawaz Ranjha, Shahid Mahmood*, Ghulam Mueen-Ud-Din, Shafeeqa Irfan, Kainat Shehzadi, Qandeel Rubab, Laiba Asad, And Marriam Ishfaq

*Institute of Food Science and Nutrition, University of Sargodha, Sargodha, Pakistan

*Corresponding author: Shahid Mahmood, Institute of Food Science and Nutrition, University of Sargodha, Sargodha, Pakistan
\end{abstract}

\section{Abstract}

Prickly pear (Opuntia ficus-indica) belongs to family cactaceae is dicotyledonous. Prickly pear is enchanted fruit because of its anti-inflammatory, anti-oxidant, antimicrobial, hypoglycemic and neuro-protective properties. Due to health prompting properties not only fruit but its stem is also used in value added products. In prickly pear vitamins, carotenoids, poly phenolic compounds and betalains are substantial phytochemicals. The flavonoids such as quercetin, isorhamnetin, kaemferol, indicaxanthin are also present in prickly pear. Prickly pear is rich source of vitamin C, E, A, B1, B2. It is also an incredible mineral source like calcium, potassium, magnesium iron or phosphorus. It also constitutes variety of amino acids like asparagine, alanine or arginine as well as carbohydrate, fibers and protein. Prickly pear is not only consumed as a food but its stem and cladodes are worthless. Due to its nutritional benefits its utilization in variety of medication is helpful against different ailment. These are effective against cancer, diabetes, obesity, ulcer, wounds, inflammation and cardiovascular diseases. Prickly pear cladodes play a major role in inhibition of gastrointestinal disorders. Vitamin $\mathrm{A}$ is beneficial in the treatment of skin disorders

Keywords:Prickly pear; Phytochemical; Anti-oxidant; Vitamins; Minerals.

\section{Introduction}

Products from natural sources are being used from centuries [1,2]. Opuntia Ficus-indica belongs to Cactaceae family is also known as prickly pear or nopal cactus. It is dicotyledonous plant represented by its miraculous adoption to arid and semi-arid climates in tropical and subtropical areas of the world. In the preceding era, many scientists and companies provides exceptional nutritional and health benefits of cactus. It is rich source of polyunsaturated fatty acid, vitamins, amino acids and polyphenols. The native prickly pear amalgam or their byproducts possess antioxidant, antimicrobial, anti-inflammatory, neuroprotective or hypoglycemic characteristics. This analysis is based on the significance of prickly pear constituents and its ameliorative effect. Moreover, we also emphasis on their biological effect that have more encouraging health benefits [3]. Cactaceae family comprises of 130 genera and 1500 species. Cactus plant is broadly spread in Mexico, Africa, American hemispheres as well as Mediterranean basin. It is used in different medicines because it plays a significant role in treatment of diseases and has anti-inflammatory, hypoglycemic effect and prevents stomach ulceration. Being antioxidant used in many countries for cure of diabetes, burns, bronchial, asthma and indigestions [4]. It is also used as pharmaceutical agent and has many medicinal and industrial benefits. Not only fruit but also its stem is used in the manufacturing of value-added products like jams, squash, wine, pickle and its seeds are used as flavoring agent. Because of its surprising biological effects, it will be promoted as a medicine. Prickly pear was examined for the achievement of liquid that is natural or sweet in taste [5]. Fruit juices $\left(16.5^{\circ} \mathrm{Brix}\right)$ were purified with enzymes. For color extraction it is treated with active carbon then it is vacuum concentrated to attain a syrup having $60^{\circ} \mathrm{Brix}$. Several physical and chemical properties like ash (\%), glucose (\%), amoroso constitution via TLC, reducing sugars (inverted sugar), OD (420 nm), viscosity (cps) or density (g/ 
$\mathrm{ml}$ ) are considered. Several sensory evaluations were also accompanied. This study revealed that cactus pear syrup had a $\mathrm{pH}$ of 4.31 , reducing sugar $52.38 \%$, viscosity 27.05 cps, acidity $0.74 \%$ and ash content is $1.4 \%$ was found. HFCS (high fructose corn syrup) concentration is $0.035 \%$ has less acidity as compared to fructose and glucose syrup that were conventional sweeteners. Glucose syrup concentration is $1.0 \%$ and is less than ash content. All differences are because of different processing techniques. The relative sweetness of fructose is less while for glucose and cactus pear it is same.

The sweetness value of cactus syrup is 67 as compared to sucrose (100). Natural products and health foods play a key role in promoting better health and elimination of diseases like cancer. Due to their unexceptional benefits they not only gain importance by experts and public but also used as a source of nutraceuticals. Because cactus fruits and cladodes possess beneficial characteristics and potentially active nutrients therefore, they are considered best for health promoting food or as a dietary supplement. Native Americans, gave value to cactus pear because of its pharmacological importance but due to lack of research this fruit is still uncommon. Recent studies describe its importance as a nutritious food or also as a medicine [6]. All the four cactus fruit varieties contain antioxidant compounds, carotenoids, conjugated flavonoids such as (kaempferol, isorhamnetin, and quercetin) as well as ascorbic acid. Quercetin was present in various kinds like O. streptacantha ( red-skinned), O.ficus-indica(green skinned) and Lindheimeri(purple-skinned) while in greenskinned, purple skinned or red skinned varieties kaempferol was present but green or purple skinned fruit contain isorhamnetin. The O.streptacantha has $(815 \mathrm{mg} / \mathrm{g} \mathrm{fw})$ ascorbic acid while Stricta var. stricta contain $(23.7 \mathrm{mg} / \mathrm{g}$ $\mathrm{fw})$ carotenoids and purple-skinned fruits have more antioxidants in them. The data described that cactus fruit contain natural antioxidants. The antioxidant capacity was due to carotenoid, flavonoid and ascorbic acid. Kingdom of Saudi Arabia (Taif) produced two prickly pear cactus varieties O.streptacantha or Stricta var. stricta have nutritionals, phytochemical and antioxidants in them. The antioxidant capacity of red varieties is more as compared to yellow varieties. The relationship exists among overall phenolic compounds or antioxidants. Iron, copper, sodium and potassium is present in almost in same amount in all samples. HPLC-UV analysis is done to recognized phenolic compounds in prickly pear. HPLC-RI analysis disclosed that sucrose is absent while glucose and fructose is present in prickly pear. The study about two prickly pear cultivars narrates about its nutritional and pharmaceutical properties. These two varieties are cultivated in arid and semiarid areas and along with industries that are located close to cactus farms [7]. Prickly pear fruit spread in South Africa, Mexico, Mediterranean area or Latin America. Because cactus pear has numerous health benefits therefore used for treatment of hypoglycemic and hypolipidemic effect in medicine [810].

\section{Discussion}

\section{Phytochemistry of Prickly Pear Fruit}

Prickly pear plants belong to family cactaceae and were produced in Africa, Europe, Australia, whole America, Asia and Mediterranean areas. The compact stem of Opuntia is known as cladodes or "pencas" [11]. The prickly pear cladodes are broadly employed in ointment for the medication of wounds, rheumatic pain, ulcer and diabetes. Therefore, these benefits are promptly admired by experimental analyses [12].

\section{Bioactive Compounds in Prickly Pear}

The fruits, herbs, oilseeds and vegetables are used worldwide as antioxidant or functional food because of instinctive phytochemicals. Prickly pear is effective source of these compounds [13]. Cactus pear aerial parts are worthless because they are beneficial source of phytochemicals. Beside natural activities they enhance the value for food or nutraceutical industry [14-16]. Cactus pear fruit or cladodes possess phytochemical compounds betalains, vitamins, carotenoids and polyphenols $[14,17,18]$. Phytochemicals such as indicaxanthin, betalains, betanin, catechin, vanillic acid or Gallic aid are present in appreciable concentration in the fruit $[19,20]$. Cactus pear retain elevated amount of phenolic content but flavonoid derivatives are crucial. In O.ficus indica, ample quantity of isorhamnetin in the form of five deviating di and triglycosides is present [21]. The remarkable health blessings are because of chemoprevantative and anti-inflammatory properties [22].

\section{Health Benefits of Bioactive Compounds}

There are huge numbers of fruits that behave as functional food. Cactus pear is one of them available in different shapes and colors. Latest study reveals the beneficial effect of prickly pear constituents that have marvelous health rewards. The yellow and red varieties of prickly pear fruit contain flavonoids, isorhamnetin and kaemferol [23]. Free radicals were stabilized that hinder the outcome of oxidative damage [24]. Current survey emphasized that biological molecule of prickly pear have remarkable health concerns therefore used in variety of medicine [25-27]. In the production of herbal medicine spongy like plant is used to obtain bioactive components by solvent. They are crucial in the manufacturing of product that contains high phytochemicals. Prickly pear fruit exhibit huge amount of polyphenols that perform anti-inflammatory and 
Table 1: Phytochemistry and beneficial impacts of bioactive compounds available in prickly pear fruit.

\begin{tabular}{|c|c|c|c|c|c|}
\hline $\begin{array}{l}\text { Bioactive } \\
\text { compound }\end{array}$ & Structure & $\begin{array}{c}\text { Molecular } \\
\text { formula }\end{array}$ & $\begin{array}{c}\text { Molecular } \\
\text { weight }\end{array}$ & Effects on human body & References \\
\hline Quercetin & ${ }^{\mathrm{H}} \mathrm{O}$ & $\mathrm{C}_{15} \mathrm{H}_{10} \mathrm{O}_{7}$ & $\begin{array}{c}302.236 \mathrm{~g} / \\
\mathrm{mol}\end{array}$ & $\begin{array}{c}\text { Quercetin is a powerful } \\
\text { nutritive polyphenol } \\
\text { having anti-proliferative, } \\
\text { anti-oxidative and anti- } \\
\text { inflammatory outcomes. } \\
\text { It has become more } \\
\text { encouraging nutraceutical } \\
\text { due of its valuable properties } \\
\text { and is widely used in the } \\
\text { prohibition of CVD. }\end{array}$ & {$[33]$} \\
\hline Kaempferol & & $\mathrm{C}_{15} \mathrm{H}_{10} \mathrm{O}_{6}$ & $\begin{array}{c}286.23 \mathrm{~g} / \\
\mathrm{mol}\end{array}$ & $\begin{array}{l}\text { It has been narrated that } \\
\text { kaempferol-provoked } \\
\text { stimulation of antioxidant } \\
\text { enzyme. The enzyme } \\
\text { performs crucial part in } \\
\text { H460 removal of cancerous } \\
\text { cells. } \\
\text { It encouraged researcher } \\
\text { that explore its molecular } \\
\text { procedure because of } \\
\text { its antioxidant and anti- } \\
\text { inflammatory properties. } \\
\text { Due to its multiple benefits } \\
\text { it is used in medication of } \\
\text { inflammatory diseases. }\end{array}$ & {$[34]$} \\
\hline Isorhamnetin & & $\mathrm{C}_{16} \mathrm{H}_{12} \mathrm{O}_{7}$ & $\begin{array}{c}316.26 \mathrm{~g} / \\
\mathrm{mol}\end{array}$ & $\begin{array}{l}\text { Prickly pear contains piscidic } \\
\text { acid (phenolic acid) and } \\
\text { isorhamnetin (flavonoid) } \\
\text { in form of glycosides. Both } \\
\text { piscidic acid as well as } \\
\text { isorhamnetin glycoside have } \\
\text { anti-hypercholesterolemic } \\
\text { properties but they are } \\
\text { revealed after cholesterol } \\
\text { percolation is prohibited in } \\
\text { vitro. But in case of O. ficus } \\
\text {-indica extracts they are } \\
\text { categorized with their anti- } \\
\text { inflammatory effect. }\end{array}$ & [35] \\
\hline
\end{tabular}

Citation: Batool Sabtain, Rabia Farooq, Bakhtawar Shafique, Muhammad Modassar Ali Nawaz Ranjha, Shahid Mahmood*, Ghulam Mueen-Ud-Din, Shafeeqa Irfan, Kainat Shehzadi, Qandeel Rubab, Laiba Asad, And Marriam Ishfaq, A Narrative Review on the Phytochemistry, Nutritional Profile and Properties of Prickly Pear Fruit.Op Acc J Bio Sci \& Res 7(2)-2021. 


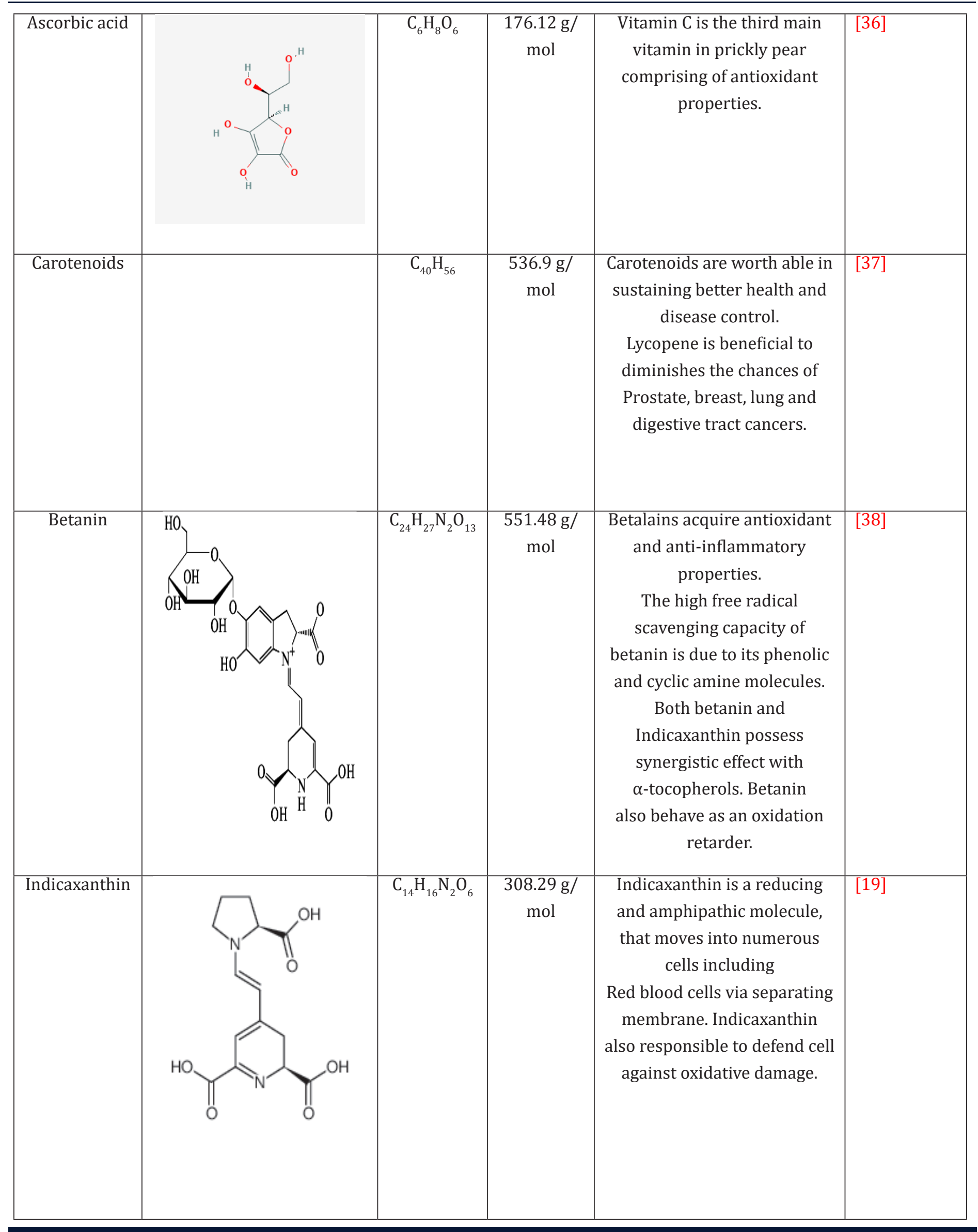

Citation: Batool Sabtain, Rabia Farooq, Bakhtawar Shafique, Muhammad Modassar Ali Nawaz Ranjha, Shahid Mahmood*, Ghulam Mueen-Ud-Din, Shafeeqa Irfan, Kainat Shehzadi, Qandeel Rubab, Laiba Asad, And Marriam Ishfaq, A Narrative Review on the Phytochemistry, Nutritional Profile and Properties of Prickly Pear Fruit.Op Acc J Bio Sci \& Res 7(2)-2021. 


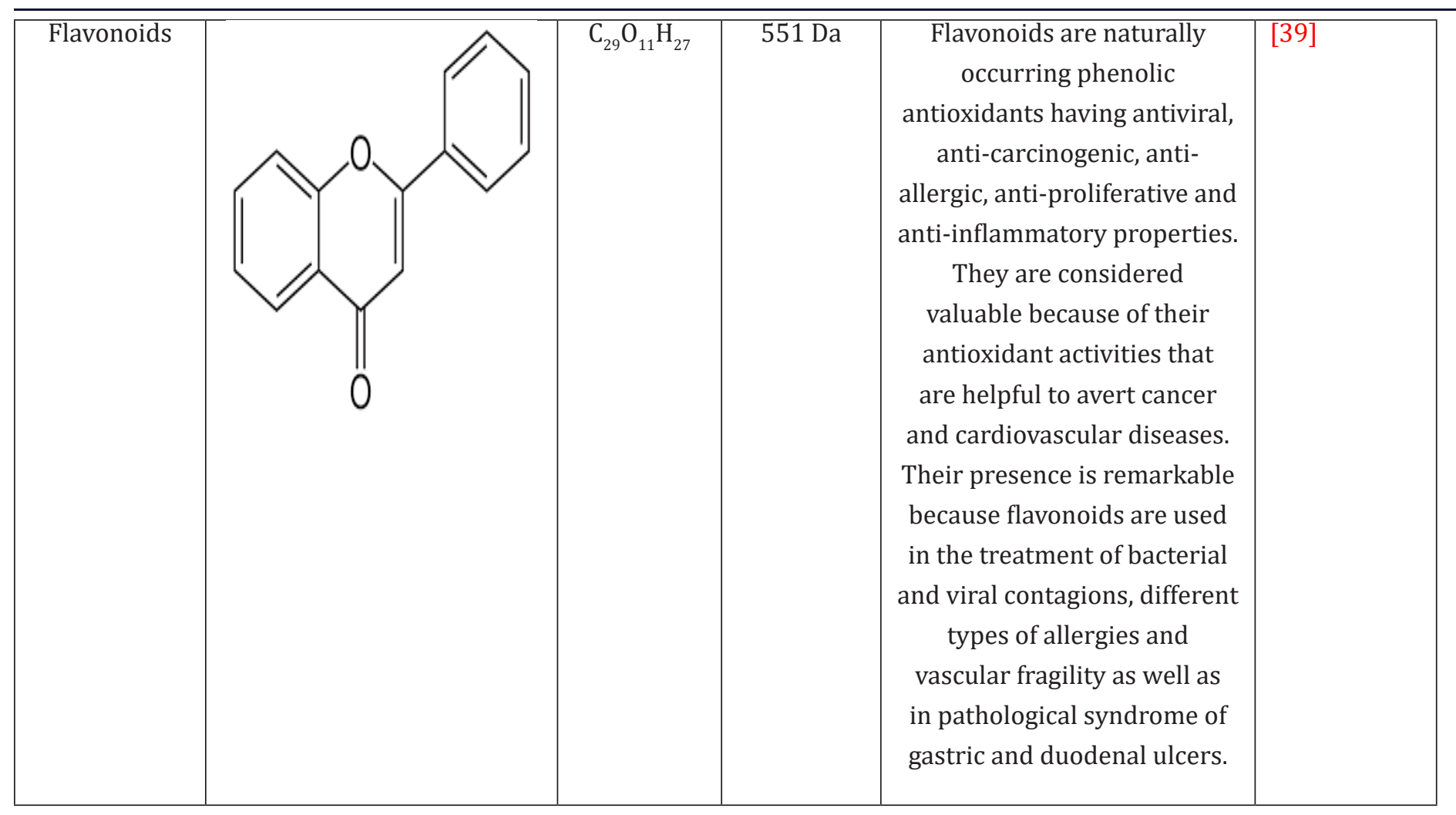

anti-oxidant activities [19,23]. Mysteriously from prickly pear fruit we separate flavonoids, alkaloids, neobetanin and indicaxanthin [28] and polysaccharides. Cladodes extracts have profuse amount of flavonoids that work against skin treatment and diabetes [29]. Prickly pear polyphenols are beneficial for human health and can be acquired by antioxidant and foraging actions. Prickly pear flowers contain enormous amount of Gallic acid because of its antioxidant property it prevent DNA from damage [30] as well as shield free radicals [31]. Hydrogen peroxide is $60 \%$ neutralize while 2,2-diphenyl-1-picrylhydrazyl radical about $44 \%$ at $4.17 \mathrm{mM}$. Gallic acid is also effective against tumor cells that results in prostate and lung cancer [32-39] (Table 1).

\section{Nutritional Profile Of Prickly Pear \\ Vitamins in Prickly Pear Fruit}

Prickly pear fruit comprises of $93 \%$ fresh mass of water, whereas other major dry matter constituents are dietary fibers or sugars like fructose or glucose. The protein content is $13 \% \mathrm{~d}$. $\mathrm{m}$ while fat is insignificant. Prickly pear fruit is valuable source of bioactive components that phenolic compounds and carotenoids, vitamins such as A, E, B1, B2 and $\mathrm{C}$ or minerals like iron, calcium, magnesium, phosphorus and potassium. Among polyphenols anthocyanin, flavonoid or phenolic acid is remarkable [40-43]. Similarly, in cactus pear numerous forms of amino acids such as asparagine, alanine or arginine are found. 0 . ficus-indica juice contain high concentration of glutamic and aspartic acid that 200 $\mathrm{mg} / \mathrm{kg}$ [44]. Prickly pear fruit contain beta-carotenes as well as vitamin $E, C$ and $K$ that are nutritionally beneficial. The constancy of fatty oil can be improved by vitamin $\mathrm{E}$ and carotenes because of their antioxidant capacity [45]. Fat-soluble vitamins (alpha-, beta-, and delta tocopherols, beta-carotene, and vitamin $\mathrm{K} 1$ ) present in seed and pulp oils of the prickly pear fruit protect lipids from oxidative damage [6]. Vitamin A is an active used in the treatment of anti-aging, as well as in skin therapy for various skin disorders [46]. These include epidermal cells renewal, extracellular matrix production, inhibition of UV induced extracellular matrix degradation, cytokine modulation, oxidant/ antioxidant, sunscreen effect, prevention of UVinduced vitamin A deficiency, and melanocyte function modulation [47]. Cactus pear contains 180 to $300 \mathrm{mg} / \mathrm{kg}$ of vitamin $\mathrm{C}$. This content is higher than that found in other common fruits like apple, banana, or grape [48]. Vitamin K1 is present in all parts of the fruit, ranging from 0.5 to $1 \mathrm{~g} / \mathrm{kg}$ $[45,49]$. Vitamin $B$ is present only in the cladodes in which it is found in trace amounts [6].

\section{Minerals in Prickly Pear Fruits}

Opuntia fruit is also considered an excellent source of mineral nutrition, being enriched in calcium, potassium, and magnesium [6]. Humans need Se in their diet for at least 25 different proteins, among which are the powerful antioxidant enzyme family of selenoglutathione peroxidases $[50,51]$. O. ficus-indica cladodes also represent a source

Citation: Batool Sabtain, Rabia Farooq, Bakhtawar Shafique, Muhammad Modassar Ali Nawaz Ranjha, Shahid Mahmood*, Ghulam Mueen-Ud-Din, Shafeeqa Irfan, Kainat Shehzadi, Qandeel Rubab, Laiba Asad, And Marriam Ishfaq, A Narrative Review on the Phytochemistry, Nutritional Profile and Properties of Prickly Pear Fruit.Op Acc J Bio Sci \& Res 7(2)-2021. 
Table 2: Vitamins in prickly pear (cactus fruit) Value per $100 \mathrm{~g}$.

\begin{tabular}{|c|c|c|c|c|c|c|c|}
\hline \multicolumn{8}{|c|}{ VITAMINS } \\
\hline Name & $\begin{array}{l}\text { Nutrient } \\
\text { Value }\end{array}$ & Unit & $\begin{array}{c}\text { Percentage of } \\
\text { RDA }\end{array}$ & $\begin{array}{l}\text { Plains prickly } \\
\text { pear, raw } \\
\text { (serving size } \\
149 \mathrm{~g} \text { ) }\end{array}$ & Unit & $\begin{array}{l}\text { Plains prickly pear, } \\
\text { broiled (serving size } \\
149 \mathrm{~g} \text { ) }\end{array}$ & Unit \\
\hline Folates & 6 & $\mu \mathrm{g}$ & 1.5 & NR & & NR & \\
\hline Niacin & 0.460 & $\mathrm{mg}$ & 3 & 0.293 & $\mathrm{mg}$ & 1.000 & $\mathrm{mg}$ \\
\hline Pyridoxine & 0.060 & $\mathrm{mg}$ & 4.5 & 0.079 & $\mathrm{mg}$ & 0.146 & $\mathrm{mg}$ \\
\hline Riboflavin & 0.060 & $\mathrm{mg}$ & 4.5 & $<0.100$ & $\mathrm{mg}$ & $<0.100$ & $\mathrm{mg}$ \\
\hline Thiamin & 0.014 & $\mathrm{mg}$ & 1 & 0.008 & $\mathrm{mg}$ & 0.018 & $\mathrm{mg}$ \\
\hline Vitamin A & 43 & IU & 1.5 & NR & & NR & \\
\hline Vitamin C & 14 & $\mathrm{mg}$ & 23 & 11.3 & $\mathrm{mg}$ & 6.2 & $\mathrm{mg}$ \\
\hline Vitamin E & $111-115$ & $\mu \mathrm{g}$ & NR & NR & & NR & \\
\hline Vitamin $K_{1}$ & 53 & $\mu \mathrm{g}$ & NR & 2.9 & $\mathrm{mg}$ & NR & \\
\hline References: & {$[54$} & & [55] & {$[56]$} & & & \\
\hline
\end{tabular}

Citation: Batool Sabtain, Rabia Farooq, Bakhtawar Shafique, Muhammad Modassar Ali Nawaz Ranjha, Shahid Mahmood*, Ghulam Mueen-Ud-Din, Shafeeqa Irfan, Kainat Shehzadi, Qandeel Rubab, Laiba Asad, And Marriam Ishfaq, A Narrative Review on the Phytochemistry, Nutritional Profile and Properties of Prickly Pear Fruit.Op Acc J Bio Sci \& Res 7(2)-2021. 
Table 3: Minerals in prickly pear (cactus fruit) Value per $100 \mathrm{~g}$.

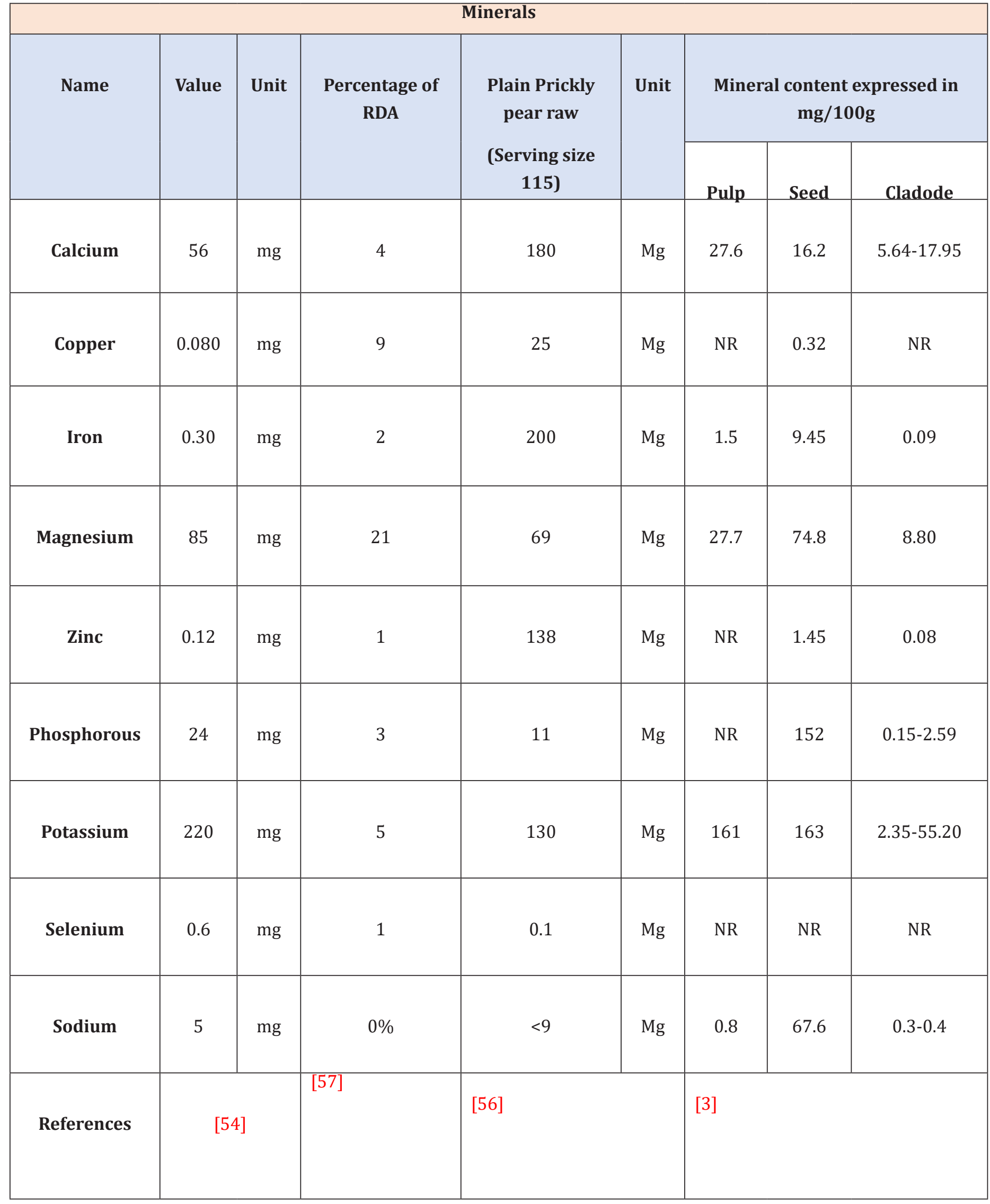


Table 4: Prickly pear nutritional profile (cactus fruit) Value per $100 \mathrm{~g}$.

\begin{tabular}{|c|c|c|c|c|}
\hline \multicolumn{5}{|c|}{ Proximate analysis of Prickly pear } \\
\hline Name & Amount in \% & $\begin{array}{c}\text { Nutritive } \\
\text { Value }\end{array}$ & Unit & Percentage of RDA \\
\hline Carbohydrate & $92.57 \pm 0.99$ & 9.57 & g & 7 \\
\hline Fat & $0.40 \pm 0$ & 0.5 & $\mathrm{~g}$ & 2.5 \\
\hline Crude fiber & $1.37 \pm 0.06$ & 3.6 & $\mathrm{~g}$ & 9 \\
\hline Protein & $1.03 \pm 0.006$ & 0.73 & $\mathrm{~g}$ & 1 \\
\hline Ash & $4.03 \pm 0.52$ & 1.64 & $\mathrm{~g}$ & NR \\
\hline Moisture content & $87.07 \pm 0.86$ & 87.55 & $\mathrm{~g}$ & NR \\
\hline References & [58] & {$[5$} & & [57] \\
\hline
\end{tabular}

of phytochemicals, such as phenolic and flavonoids [52] minerals, and other nutrients. The potential benefits of the high calcium content are negligible because it is in the form of poorly bioavailable calcium oxalate crystals [53-58].

Proximate Composition of Prickly Pear Fruit

The main constituent of $O$. ficus-indica cladodes is water (80-95\%), followed by small amounts of carbohydrates (3$7 \%)$, fiber (1-2\%), and protein (0.5-1\%); other compounds are only partly known and have not been quantitatively determined [18] (Tables 2-4).

Properties of Prickly Pear

\section{Anti-Oxidative Agent}

Prickly pear has defensive properties because of presence of antioxidant compounds like vitamin C, vitamin E, betalains, polyphenols as flavonoids and phenolic acids [59]. Vitamin $\mathrm{C}$ acts as a reducing agent and have antioxidant capacity [60]. In prickly pear several enzymatic and non-enzymatic reactions are due to availability of huge quantity of antioxidant that has scavenging number of reactive oxygen species. Vitamin C protects DNA and cellular tissues from deterioration caused by free radical compounds. It is also essential in the prohibition of cancer, heart diseases, hypertension and osteoporosis. Antioxidants protect body's defense system by lowering the prooxidant activity [61]. The prooxidant constitute of reactive oxygen species and its products. If oxidative stress increases it cause diseases like cardiovascular, cerebrovascular and cancer. Prickly pear fruit betalains and ascorbic acid act as antioxidants because they play vital part in boosting body's redox balance and decrease lipid oxidation by acting as radical scavengers [62]. Anti-Inflammatory Agent
Opuntia ficus indica have anti-inflammatory effect [63]. The anti-inflammatory activity of hydrocortisone is greater as compared to $\beta$-Sitosterol that is obtained from stem extract. Measure of anti-inflammatory activity the nitric oxide radical (NO) scavenging assay is used commonly because of its indication in inflammation [64]. Due to its presence in physiological and pathological process prohibition of hyaluronidase assay is another way of determining antiinflammatory action.

\section{Anti-Hyperlipidemic Agent}

The prickly pear is used in medicine because of its hypoglycemic and hypolipidemic properties [8-10]. Prickly pear cladodes are of great importance because of fibers and antioxidant compounds [12]. They are beneficial in the treatment of chronic diseases. Cladodes are also helpful in preventing gastrointestinal disorders by improving body mass and glycaemia. They also act as anti-hyperlipidemic agent.

\section{Anticholesterolemic Properties}

Prickly pear is using for centuries as food sources and also in traditional folk medicines due to their nutritional properties and their benefit in chronic diseases. These include diabetes, obesity, cardiovascular, cancer, and many other diseases. It exhibits the properties due to high content of antioxidant, pigments (carotenoids and Berlin's) and phenolic acid [65]. Cardiovascular diseases are becoming the cause of death worldwide. In developing countries, the rate of it is increasing. In Mexico, mortality rate due to cardiovascular disease has increased which is $11 \%$ of deaths in country by 2006 [66]. Lifestyle changing has increased the rate of cardiovascular diseases in Mexico [67]. Prickly pear

Citation: Batool Sabtain, Rabia Farooq, Bakhtawar Shafique, Muhammad Modassar Ali Nawaz Ranjha, Shahid Mahmood*, Ghulam Mueen-Ud-Din, Shafeeqa Irfan, Kainat Shehzadi, Qandeel Rubab, Laiba Asad, And Marriam Ishfaq, A Narrative Review on the Phytochemistry, Nutritional Profile and Properties of Prickly Pear Fruit.Op Acc J Bio Sci \& Res 7(2)-2021. 
has antiatherogenic properties which is due to the high antioxidant which decrease the per oxidant, an important risk factor in atherosclerosis [12]. Prickly pear prevent the cardiovascular diseases.

According to several reports prickly pear has the antioxidant and antiatherogenic properties [12]. The consumption of prickly pear juice and fruit help to remove oxidative stress [61]. Similarly, the consumption of dried leaves from ficus-indica as dietary supplement by the women which was affected with metabolic syndrome cause a rapid increase in circulating HDL level by decrease in LDL cholesterol and in triglycerides, which indicates that the plant has hypocholesterolemic effect [68]. These properties are due to their content in dietary fiber which lowers the cholesterol level in hyperglycemic non-diabetic human patient.

\section{Anti-Arthrosclerosis Property}

Prickly pear improves the platelet function and homeostatic balance; thus it is used to prevent the atherosclerosis risk [12].

\section{Anti-Diabetic Property}

In type 2 diabetes mellitus it is multifactorial disease and also includes the genetic determinants of individual susceptibility. By the ingestion of prickly pear the mechanism of hypoglycemic evoke, which slows down absorption of glucose and increase the viscosity of food in gut $[69,70]$. .Another benefit is that prickly pear can stimulate the insulin secretion by direct action on pancreatic beta cell [71]. Several reports in diabetic patients showed the antihyperglycemic effect of prickly pear. Prickly pear plays a vital role in prevention of cardiovascular complications due to type 2 diabetes mellitus. Indeed, oxidative stress plays a major role in the pathophysiology of type 2 diabetes mellitus, particularly in the development of accelerated atherosclerosis lesions and cardiovascular diseases, which represent a main complication in diabetes [72].

\section{Anti-Obesity Property}

Obesity is major problem in all aver the world. In Mexico, the obesity rate has increased $32 \%$ (higher ratio in females) and $15 \%$ in children. Mexico is highly facing the situation of obesity. People find difficulties in exercise that can improve the symptoms of obesity. The demand for weight-loss products based on plants has increased during the last decade. This demand clearly indicates that medicinal plants for the treatment of obesity represent a current topic of interest. O. ficus-indica fruits, stems, seeds and cladodes have been traditionally used in folk medicine to prevent and cure chronic diseases. Therefore, clinical pharmacologic interest in the efficacy and safety of the phytochemicals present in the genus Opuntia has grown during recent years due to the realization that many people self-medicate using this plant $[3,73]$. Different approaches can be used, including in vitro on cellular models, in vivo by the use of animal models such as mice or rats feed diets enriched with Opuntia extracts, and human clinical trials. In adipocytes morphology, gene expression and hormone sensitivity the changes occur in it due to the complex process which is adipogenesis. Adipocyte plays major role in the maintenance of the lipid homeostasis and it balances the energy by storing the triglyceride to change the energy demand. Obesity is not only due to the hypertrophy adipose tissue but also due to the hyperplasia adipose tissue $[74,75]$ and the risk of the obesity is controlled by the prickly pear efficiently. Litramine that is natural complex fiber derived from the prickly pear is used in hypo caloric diet and also for the moderate physical activity. Litramine is important in reducing the weight and there is no adverse effect of it on human health. Prickly pear derived fiber is useful for weight loss because it increases the excretion process and decreases the absorption process in the body. On the other hand, other weight loss substances can damage the body parts and have adverse effect but prickly pear does not have the negative effect on human body. Intake of the prickly pear helps in the balanced diet [76 77]. We use the animals to check the effect of the prickly pear for obesity. The diet which have the prickly pear powder effect the serum lipid profile and glucose it is also linked with effects such as on atherosclerosis, diabetes and obesity [78]. It has impact on the insulin sensitivity by the regulation of the genes which involved in the adipocyte differentiation [79]. This experiment was done on the mice the prickly pear was added in the high fat diet and noticed to the mice for the 12 weeks. Mice got the less weight and had the lower circulating cholesterol, LDL cholesterol and HDL cholesterol [66].

\section{Anti-Carcinogenic Properties}

The juice of prickly pear contains phenolic, flavonoids, betalains and antioxidant activity. Among the tested lines of cancer, viability of colon and prostate cells were highly affected. Researchers shows that by taking the prickly pear juice at different intervals prevent the oxidative stress and cancer [80]. Prickly pear is also used to lower the effect of the hangover. If we take the prickly pear before the alcohol it reduces the effect of the alcohol. It also reduces the nausea, dry mouth and anorexia. Loss of appetite was also reduced for volunteer who took the prickly pear. But it does not reduce the other symptoms of the hangover like headache and vomiting etc.

\section{Improving Skin Property}

Skin is the largest organ of the human body. It controls many functions of the body. It also maintains the temperature of human body and removes the toxic compounds through

Citation: Batool Sabtain, Rabia Farooq, Bakhtawar Shafique, Muhammad Modassar Ali Nawaz Ranjha, Shahid Mahmood*, Ghulam Mueen-Ud-Din, Shafeeqa Irfan, Kainat Shehzadi, Qandeel Rubab, Laiba Asad, And Marriam Ishfaq, A Narrative Review on the Phytochemistry, Nutritional Profile and Properties of Prickly Pear Fruit.Op Acc J Bio Sci \& Res 7(2)-2021. 
the transpiration. Although skin also has the antioxidants that help in the regeneration of the skin and helps in the wound healing. It also removes the damaged biomolecules. The wound healing process is slow in the diabetic patients and also in people that have the high stress level, decrease immune response and infectious agents [81]. The extract of the prickly pear has been used for the skin burn, skin disorders and wound healing [82].

Conclusion

Cactus pear is rich in vitamins, minerals and antioxidant therefore its importance can't be denied. Due to its health promoting and nutritional properties it makes its way in market crops. In brief, future research is needed to explore additional benefits and miraculous properties of this plant. Instead of using the medicines which also harm the human body, we can use the food for curing the diseases which have a good effect on the health and do not deteriorate the life of a patient. The whole fruit of prickly pear is good for consumption as it contains the antioxidant and many other diseases curing properties. It is also the important source of the vitamins, minerals, betalains, bioactive and polyphenol compounds. So use this food instead of the medicines because it has a long-lasting effect on the body. This review focuses on the Phytochemistry, nutritional value, and health benefits of prickly pear.

\section{Conflict of Interest}

Author finds no conflict of interest.

\section{References}

1. Ranjha MMAN, Amjad S, Ashraf S, Mahmood S, Murtaza MA (2020) Extraction of Polyphenols from Apple and Pomegranate Peels Employing Different Extraction Techniques for the Development of Functional Date Bars Extraction of Polyphenols from Appl ... Extraction of Polyphenols from Apple and Pomegranate Peels Employing D. Int. J. Fruit Sci pp. 1-21.

2. Ranjha MMAN, Irfan S, Nadeem M, Mahmood S (2020) A Comprehensive Review on Nutritional Value, Medicinal Uses, and Processing of Banana. Food Rev. Int.

3. El-Mostafa K (2014) Nopal cactus (Opuntia ficus-indica) as a source of bioactive compounds for nutrition, health and disease. Molecules 19(9): 14879-14901.

4. Kaur M, Kaur A, Sharma R (2012) Pharmacological actions of Opuntia ficus indica: A review. J. Appl. Pharm. Sci 2(7): 15-18.

5. Sáenz C, Estévez AM, Sepúlveda E, Mecklenburg P (1998) Cactus pear fruit: A new source for a natural sweetener. Plant Foods Hum. Nutr 52(2): 141-149.

6. Feugang JM, Konarski P, Zou D, Stintzing FC, Zou C (2006) Nutritional and medicinal use of Cactus pear (Opuntia spp.) cladodes and fruits. Front. Biosci 11(2): 2574-2589.

7. Abdel-Hameed ESS, Nagaty MA, Salman MS, Bazaid SA (2014) Phytochemicals, nutritionals and antioxidant properties of two prickly pear cactus cultivars (Opuntia ficus indica Mill.) growing in Taif, KSA.
Food Chem 160: 31-38.

8. Frati AC, Jiménez E, Ariza CR (1990) Hypoglycemic effect of Opuntia ficus indica in non insulin-dependent diabetes mellitus patients. Phyther. Res 4(5): 195-197.

9. Hegwood DA (2019) Human Health Discoveries with Opuntia sp. (Prickly Pear). HortScience 25(12): 15151516.

10. Fernandez ML, Lin ECK, Trejo A, McNamara DJ (1992) Prickly pear (Opuntia sp.) pectin reverses low density lipoprotein receptor suppression induced by a hypercholesterolemic diet in guinea pigs. J. Nutr 122(12): 2330-2340.

11. Sumaya-Martínez MT (2011) Betalain, acid ascorbic, phenolic contents and antioxidant properties of purple, red, yellow and white cactus pears. Int. J. Mol. Sci 12(10): 6452-6468.

12. Osuna-martínez U, Reyes-esparza J, Rodríguez-fragoso L (2014) Cactus (Opuntia ficus-indica): A Review on its Antioxidants Properties and Potential Pharmacological Use in Chronic Diseases. Nat. Prod. Chem. Res 2(6): 2-9.

13. Lee JC, Kim HR, Kim J, Jang YS (2002) Antioxidant property of an ethanol extract of the stem of Opuntia ficus-indica var. saboten. J. Agric. Food Chem 50(22): 6490-6496.

14. Barba FJ (2017) Impact of conventional and nonconventional processing on prickly pear (Opuntia spp.) and their derived products: From preservation of beverages to valorization of by-products. Trends Food Sci. Technol 67: 260-270.

15. Msaddak L (2017) Opuntia ficus-indica cladodes as a functional ingredient: bioactive compounds profile and their effect on antioxidant quality of bread. Lipids Health Dis 16(1): 1-8.

16. Sánchez-Tapia M (2017) Nopal (Opuntia ficus indica) protects from metabolic endotoxemia by modifying gut microbiota in obese rats fed high fat/sucrose diet. Sci. Rep 7(1): 1-16.

17. Fernández-López JA, Almela L, Obón JM, Castellar R (2010) Determination of Antioxidant Constituents in Cactus Pear Fruits," Plant Foods Hum. Nutr 65(3): 253-259.

18. Stintzing FC (2005) Color, betalain pattern, and antioxidant properties of cactus pear (Opuntia spp.) clones. J. Agric. Food Chem 53(2): 442-451.

19. Butera D (2002) Antioxidant activities of sicilian prickly pear (Opuntia ficus indica) fruit extracts and reducing properties of its betalains: Betanin and indicaxanthin. J. Agric. Food Chem 50(23): 6895-6901.

20. Guzmán-Maldonado SH, Morales-Montelongo AL, Mondragón-Jacobo C, Herrera-Hernández G, GuevaraLara F, et al. (2010) Physicochemical, nutritional, and functional characterization of fruits xoconostle (opuntia matudae) pears from central-México Region. J. Food Sci 75(6):C485-492.

21. Santos-Zea L, Gutiérrez-Uribe JA, Serna-Saldivar SO (2011) Comparative analyses of total phenols, antioxidant activity, and flavonol glycoside profile of cladode flours from different varieties of opuntia spp. J. Agric. Food Chem 59(13): 7054-7061.

22. Antunes-Ricardo M, Rodríguez-Rodríguez C, GutiérrezUribe JA, Cepeda-Cañedo E, Serna-Saldívar SO (2017) Bioaccessibility, intestinal permeability and plasma

Citation: Batool Sabtain, Rabia Farooq, Bakhtawar Shafique, Muhammad Modassar Ali Nawaz Ranjha, Shahid Mahmood*, Ghulam Mueen-Ud-Din, Shafeeqa Irfan, Kainat Shehzadi, Qandeel Rubab, Laiba Asad, And Marriam Ishfaq, A Narrative Review on the Phytochemistry, Nutritional Profile and Properties of Prickly Pear Fruit.Op Acc J Bio Sci \& Res 7(2)-2021. 
stability of isorhamnetin glycosides from opuntia ficusindica (L.). Int. J. Mol. Sci. 18(8): 1-15.

23. Kuti JO (2004) Antioxidant compounds from four Opuntia cactus pear fruit varieties. Food Chem 85(4): 527-533,

24. Galati EM (2003) Chemical characterization and biological effects of sicilian Opuntia ficus indica (L.) Mill. fruit juice: Antioxidant and antiulcerogenic activity. J. Agric. Food Chem 51(17): 4903-4908.

25. Alimi $H$ (2010) Antioxidant and antiulcerogenic activities of Opuntia ficus indica f. inermis root extract in rats. Phytomedicine, 17(14): 1120-1126.

26. Morales P, Ramírez-Moreno E, de C. Sanchez-Mata M, Carvalho AM (2012) Nutritional and antioxidant properties of pulp and seeds of two xoconostle cultivars (Opuntia joconostle F.A.C. Weber ex Diguet and Opuntia matudae Scheinvar) of high consumption in Mexico. Food Res. Int 464(1): 279-285.

27. Valente LMM (2010) Antiradical activity, nutritional potential and flavonoids of the cladodes of Opuntia monacantha (Cactaceae). Food Chem 123(4): 1127-1131.

28. Valente LMM (2007) Evaluation of the antitumor and trypanocidal activities and alkaloid profile in species of Brazilian Cactaceae. Pharmacogn. Mag 3(11): 167.

29. Yang N (2008) Anti-diabetic effects of polysaccharides from Opuntia monacantha cladode in normal and streptozotocin-induced diabetic rats. Innov. Food Sci. Emerg. Technol 9(4): 570-574.

30. Khan NS, Ahmad A, Hadi SM (2000) Anti-oxidant, prooxidant properties of tannic acid and its binding to DNA. Chem. Biol. Interact 125(3): 177-189.

31. Yen GC, Der Duh P, Tsai HL (2002) Antioxidant and prooxidant properties of ascorbic acid and gallic acid. Food Chem 79(3): 307-313.

32. You BR, Park WH (2010) Gallic acid-induced lung cancer cell death is related to glutathione depletion as well as reactive oxygen species increase. Toxicol. Vitr 24(5): 1356-1362.

33. Boots AW, Haenen GRMM, Bast A (2008) Health effects of quercetin: From antioxidant to nutraceutical. Eur. J. Pharmacol.585 (2-3): 325-337.

34. Leung HWC, Lin CJ, Hour MJ, Yang WH, Wang MY et al. (2007) Kaempferol induces apoptosis in human lung nonsmall carcinoma cells accompanied by an induction of antioxidant enzymes. Food Chem. Toxicol 45(10): 20052013.

35. Jiang JS, Shih CM, Wang SH, Chen TT, Lin CN, et al. (2006) Mechanisms of suppression of nitric oxide production by 3-0-methylquercetin in RAW 264.7 cells. J. Ethnopharmacol 103(2): 281-287.

36. Joana Gil-Chávez G (2013) Technologies for Extraction and Production of Bioactive Compounds to be Used as Nutraceuticals and Food Ingredients: An Overview. Compr. Rev. Food Sci. Food Saf 12(1): 5-23.

37. Gammone MA, Riccioni G, D’Orazio N (2015) Carotenoids: Potential allies of cardiovascular health?. Food Nutr. Res 59: 26762.

38. MAL, Tesoriere L (2013) Lipoperoxyl Radical Scavenging and Antioxidative Effects of Red Beet Pigments.Red Beet Biotechnol. Food Pharm. Appl 1-435.
39. Ren W, Qiao Z, Wang H, Zhu L, Zhang L (203) Flavonoids: Promising anticancer agents.Med. Res. Rev 23(4): 519 534.

40. Bayar N, Kriaa M, Kammoun R (2016) Extraction and characterization of three polysaccharides extracted from Opuntia ficus indica cladodes. Int. J. Biol. Macromol 92: 441-450.

41. Farag MA, Maamoun AA, Ehrlich A, Fahmy S, Wesjohann LA (2017) Assessment of sensory metabolites distribution in 3 cactus Opuntia ficus-indica fruit cultivars using UV fingerprinting and GC/MS profiling techniques. LWT Food Sci. Technol 80: 145-154.

42. Mill o (2016) Wartość odżywcza i właściwości prozdrowotne opuncji The nutritional value and health benefits of fig prickly pear 17(3): 213-217.

43. Berrabah H, Taïbi K, Ait Abderrahim L, Boussaid M (2019) Phytochemical composition and antioxidant properties of prickly pear (Opuntia ficus-indica L.) flowers from the Algerian germplasm. J. Food Meas. Charact 13(2): 11661174.

44. Kugler F, Graneis S, Schreiter PPY, Stintzing FC, Carle $\mathrm{R}$ (2006) Determination of free amino compounds in betalainic fruits and vegetables by gas chromatography with flame ionization and mass spectrometric detection. J. Agric. Food Chem 54(12): 4311-4318.

45. Ramadan MF, Mörsel JT (2003) Recovered lipids from prickly pear [Opuntia ficus-indica (L.) Mill] peel: A good source of polyunsaturated fatty acids, natural antioxidant vitamins and sterols. Food Chem 83(3): 447-456.

46. Morales JO, Valdés $\mathrm{K}$, Morales J, Oyarzun-Ampuero F (2015) Lipid nanoparticles for the topical delivery of retinoids and derivatives. Nanomedicine 10(2): 253-269.

47. Liu J, $\mathrm{Hu}$ W, Chen $\mathrm{H}, \mathrm{Ni} \mathrm{Q}, \mathrm{Xu} \mathrm{H}$, et al. (2007) Isotretinoinloaded solid lipid nanoparticles with skin targeting for topical delivery. Int. J. Pharm 328(2): 191-195.

48. Piga A (2004) Cactus pear: A fruit of nutraceutical and functional importance. J. Prof. Assoc. Cactus Dev6: 9-22.

49. Fawzy Ramadan M, Mörsel JT (2003) Lipid profile of prickly pear pulp fractions. Food, Agric. Environ 1(2): 6670.

50. Whanger PD (2002) Selenocompounds in Plants and Animals and their Biological Significance. J. Am. Coll. Nutr 21(3): pp. 223-232.

51. Ellis DR, Salt DE, (2003) Plants, selenium and human health. Curr. Opin. Plant Biol 6(3): 273-279.

52. Lee et al EH (2003) Constituents of the stems and fruits of Opuntia ficus-indica var. saboten. Arch. Pharm. Res 26(12): 1018-1023.

53. McConn MM, Nakata PA, (2004) Oxalate Reduces Calcium Availability in the Pads of the Prickly Pear Cactus through Formation of Calcium Oxalate Crystals. J. Agric. Food Chem 52(5): 1371-1374.

54. Rudrappa U (2019) No Title Prickly pear nutritional facts.

55. Cota-Sánchez H (2015) Nutritional Composition of the Prickly Pear (Opuntia ficus-indica) Fruit. in Nutritional Composition of Fruit Cultivars 691-712.

56. Phillips KM (2014) Nutrient composition of selected traditional United States Northern Plains Native American plant foods. J. Food Compos. Anal 34(2): 136-152. 
57. USDA SL (2019) Prickly pear raw.

58. Mehdi Dahmardeh (2012) The effect of polythene colour container and three spawn rates on production of Pleurotus ostreatus mushroom. African J. Biotechnol 11(39).

59. Butera D (2002) Antioxidant activities of sicilian prickly pear (Opuntia ficus indica) fruit extracts and reducing properties of its betalains: Betanin and. J. Agric. Food Chem 50(23): 6895-6901.

60. Lobo V, Patil A, Phatak A, Chandra N (2010) Free radicals, antioxidants and functional foods: Impact on human health. Pharmacogn. Rev 4(8): 118-126.

61. Tesoriere L, Butera D, Pintaudi AM, Allegra M, Livrea MA (2004) Supplementation with cactus pear (Opuntia ficusindica) fruit decreases oxidative stress in healthy humans: A comparative study with vitamin C. Am. J. Clin. Nutr 80(2): 391-395.

62. Du Toit A, De Wit M, Osthoff G, Hugo A (2018) Relationship and correlation between antioxidant content and capacity, processing method and fruit colour of cactus pear fruit. Food Bioprocess Technol 11(8): 1527-1535.

63. Park EH, Kahng JH, Lee SH, Shin, KH (2001) An antiinflammatory principle from cactus. Fitoterapia 72(3): 288-290.

64. González-Peña D, Colina-Coca C, Char CD, Cano MP, De Ancos B, et al. (2013) Hyaluronidase inhibiting activity and radical scavenging potential of flavonols in processed onion. J. Agric. Food Chem 61(20): 4862-4872.

65. Del Socorro Santos DIáz M, Barba De La Rosa AP, HélièsToussaint $C$, Guéraud F, Nègre-Salvayre A (2017) Opuntia spp.: Characterization and Benefits in Chronic Diseases. Oxid. Med. Cell. Longev 2017: 8634249.

66. Rodríguez T (2006) Trends in mortality from coronary heart and cerebrovascular diseases in the Americas: 19702000. Heart 92(4): 453-460.

67. Acosta-Cázares B, Escobedo-De La Peña J (2010) High burden of cardiovascular disease risk factors in Mexico: An epidemic of ischemic heart disease that may be on its way?. Am. Heart J 160(2): 230-236.

68. Linarès $E$, Thimonier $C$, Degre $M$ (2007) The effect of neopuntia ${ }^{\circledR}$ on blood lipid parameters-Risk factors for the metabolic syndrome (Syndrome $\chi$ ). Adv. Ther 24(5): 1115-1125.

69. Shapiro K, Gong WC (2002) Natural products used for diabetes. J. Am. Pharm. Assoc. (Washington, D.C. 1996) 42(2): 217-226.

70. Lopez J, Jose Luis (2018) Use of Opuntia Cactus as a Hypoglycemic Agent in Managing Type 2 Diabetes Mellitus among Mexican American Patients. Nutr. Bytes 12(1).
71. Butterweck V, Semlin L, Feistel B, Pischel I, Bauer K, et al. (2011) Comparative evaluation of two different Opuntia ficus-indica extracts for blood sugar lowering effects in rats. Phyther. Res 25(3): 370-375.

72. Giacco F. Brownlee, M (2010) Oxidative stress and diabetic complications. Circ. Res 107(9): 1058-1070.

73. Alonso-Castro AJ, Domínguez F, Zapata-Morales JR, Carranza-Álvarez C (2015) Plants used in the traditional medicine of Mesoamerica (Mexico and Central America) and the Caribbean for the treatment of obesity. J. Ethnopharmacol 175: 335-345.

74. Lee YJ, Choi HS, Seo MJ, Jeon HJ, Kim KJ, et al. (2015) Kaempferol suppresses lipid accumulation by inhibiting early adipogenesis in 3T3-L1 cells and zebrafish. Food Funct 6(8): 2824-2833.

75. Lee J (2009) Isorhamnetin represses adipogenesis in 3T3L1 cells. Obesity 17(2): 226-232.

76. Grube B, Chong PW, Lau KZ, Orzechowski HD (2013) A natural fiber complex reduces body weight in the overweight and obese: A double-blind, randomized, placebo-controlled study. Obesity 21(1): 58-64.

77. Uebelhack R, Busch R, Alt F, Beah ZM, Chong PW (2014) Effects of Cactus Fiber on the Excretion of Dietary Fat in Healthy Subjects: A Double Blind, Randomized, PlaceboControlled, Crossover Clinical Investigation. Curr. Ther. Res. - Clin. Exp 76: 39-44.

78. Ennouri M, Fetoui H, Bourret E, Zeghal N, Attia H (2006) Evaluation of some biological parameters of Opuntia ficus indica. 1. Influence of a seed oil supplemented diet on rats. Bioresour. Technol 97(12): 1382-1386.

79. Kang J, Lee J, Kwon D, Song Y (2013) Effect of Opuntia humifusa supplementation and acute exercise on insulin sensitivity and associations with PPAR- $\gamma$ and PGC- $1 \alpha$ protein expression in skeletal muscle of rats. Int. J. Mol. Sci 14(4): 7140-7154.

80. Chavez-Santoscoy RA, Gutierrez-Uribe JA, Serna-Saldívar SO (2009) Phenolic composition, antioxidant capacity and in vitro cancer cell cytotoxicity of nine prickly pear (Opuntia spp.) juices. Plant Foods Hum. Nutr 64(2): 146152.

81. Guo S, DiPietro LA (2010) Critical review in oral biology $\&$ medicine: Factors affecting wound healing. J. Dent. Res 89(3): 219-229.

82. De Azevedo Ribeiro RC, Barreto SMAG, Ostrosky EA, Da Rocha-Filho PA, Veríssimo LM, et al. (2015) Production and characterization of cosmetic nanoemulsions containing Opuntia ficus-indica (L.) Mill extract as moisturizing agent. Molecules 20(2): 2492-2509.

\section{*Corresponding author: Shahid Mahmood, Email: Shahid.mustafa@uos.edu.pk}

Next Submission with BGSR follows:

- Rapid Peer Review

- Reprints for Original Copy

- E-Prints Availability

- Below URL for auxiliary Submission Link: https://biogenericpublishers.com/submit-manuscript/

Citation: Batool Sabtain, Rabia Farooq, Bakhtawar Shafique, Muhammad Modassar Ali Nawaz Ranjha, Shahid Mahmood*, Ghulam Mueen-Ud-Din, Shafeeqa Irfan, Kainat Shehzadi, Qandeel Rubab, Laiba Asad, And Marriam Ishfaq, A Narrative Review on the Phytochemistry, Nutritional Profile and Properties of Prickly Pear Fruit.Op Acc J Bio Sci \& Res 7(2)-2021. 